\title{
Sustaining the Technopolis: The Case of Austin, Texas
}

\author{
${ }^{\dagger}$ David V. Gibson and John S. Butler \\ $I^{2}$ Institute, The University of Texas at Austin, USA
}

\begin{abstract}
In "Creating the Technopolis: High Technology Development in Austin Texas," Smilor, Kozmetsky, and Gibson (1988) make the case that in the mid-1980s Austin was becoming a globally competitive high tech region. Indeed over the years and into 2013, Austin has established its reputation as a leading entrepreneurial and technology center and "talent magnet." Delegations from across the US and worldwide visit Austin to better understand how this central Texas city went from being a state government and university town to become a fast growing, globally competitive, technology hotspot leading the state and nation in job creation. Central to the concept of the Triple Helix and Technopolis Frameworks is the importance of university, business, and government cooperation. This paper gives examples of mechanisms, processes, and metrics on how The University of Texas at Austin; regional technology industry; federal, state, and local government policies; and support groups all contributed to growing and sustaining the Austin Technopolis.
\end{abstract}

Keyword: Technopolis, Triple Helix, Regional Development, Regional Cooperation, Entrepreneurship, Technology Transfer

\section{INTRODUCTION}

The Triple Helix thesis (Viale and Etzkowitz 2010) is that the potential for innovation and economic development in a knowledge society lies in a more prominent role for the university and the hybridization of elements from university, industry and government to generate new institutional and social formats for the production, transfer and application of

${ }^{\dagger}$ The authors thank the following for reviewing and otherwise contributing to this research paper: Jim Butler, Manager, Creative Industries, City of Austin; Beverly Kerr, VP Research, Austin Chamber of Commerce; Betsy Merrick, Associate Director, Marketing/Public Relations, Office of Technology Commercialization, UT Austin; and Susan Wyatt Sedwick, Associate Vice President for Research and Director, Office of Sponsored Projects, UT Austin.; James Jarrett, Senior Research Scientist, IC Institute; Margaret Cotrofeld, Research Assistant and Technical Writer, IC Institute, The University of Texas at Austin and Fred Phillips, College of Engineering and Applied Sciences, Stony Brook University, State University of New York.

*Correspondence to : Prof. David V. Gibson

IC $^{2}$ Institute, The University of Texas at Austin, USA

E-mail : davidg@ic2.utexas.edu

World Technopolis Review

Copyright $\odot$ World Technopolis Association

CC This is an open-access article distributed under the terms of the Creative Commons Attribution Non-Commercial License(http://creativecommons.org/icenses/by-nc/3.0) which permits unrestricted noncommercial use, distribution, and reproduction in any medium, provided the original work is properly cited knowledge. The Triple Helix concept relies on three main ideas: (1) a more prominent role for the university in innovation, on a par with industry and government in the knowledge society; (2) a movement toward collaborative relationships among the three major institutional spheres, in which innovation policy is increasingly an outcome of interaction; and (3) in addition to fulfilling their traditional functions, each institutional sphere also "takes the role of the other" performing new roles as well as their traditional function (Triple Helix Research Group 2013). The Technopolis Framework (Smilor, Gibson and Kozmetsky 1988) adds the support groups sector to the Triple Helix as well as a finer delineation of the academic, business, and government sectors. The support groups sector, which is key to innovation ecosystem development, includes such things as VC and angel financing, legal and management talent, professional and industry associations, entrepreneurship support activities, chambers of commerce, non-profit and non-government organizations, etc. As stated by Saxenian (1994), support groups are a segment of regional institutions that set the tone for social interaction, and both influence and are influenced by the culture of a region.

Institutional excellence in any sector or subsector is not 
sufficient. As emphasized in both the Triple Helix and Technopolis Frameworks it is the interaction or networking across sectors that is most important and that sets regions apart in terms of their creative and innovative capacity (Smilor et.al. 1988; Gibson and Rogers 1994; Phillips 2008). As noted in $<$ Fig. $1>$, we identify the key role of influencers across mechanisms, processes, and metrics as linking the university, business, government, and support groups. Mechanisms include such things as policy (e.g., the Bayh Dole Act or governmental research funding agencies). Structures include such entities as science parks, incubators and business accelerators. Processes focus on how these policies and structures are managed. For example, is com- munication highly structured and vertical or is it more informal and horizontal? Is there a high tolerance for entrepreneurial risk taking and the ability to try again, i.e., is failure seen as an important learning activity or as the end of an individual's entrepreneurial career? Metrics concern how results are measured and often determine or at least influence behavior. Are key metrics the number of patents a university generates or the number of published articles? Is it the amount of research funding, the impact of the research, or commercial applications? In short, mechanisms, processes, and metrics have a great deal to do with facilitating or frustrating win-win-win activities across the Triple Helix or Technopolis Framework.

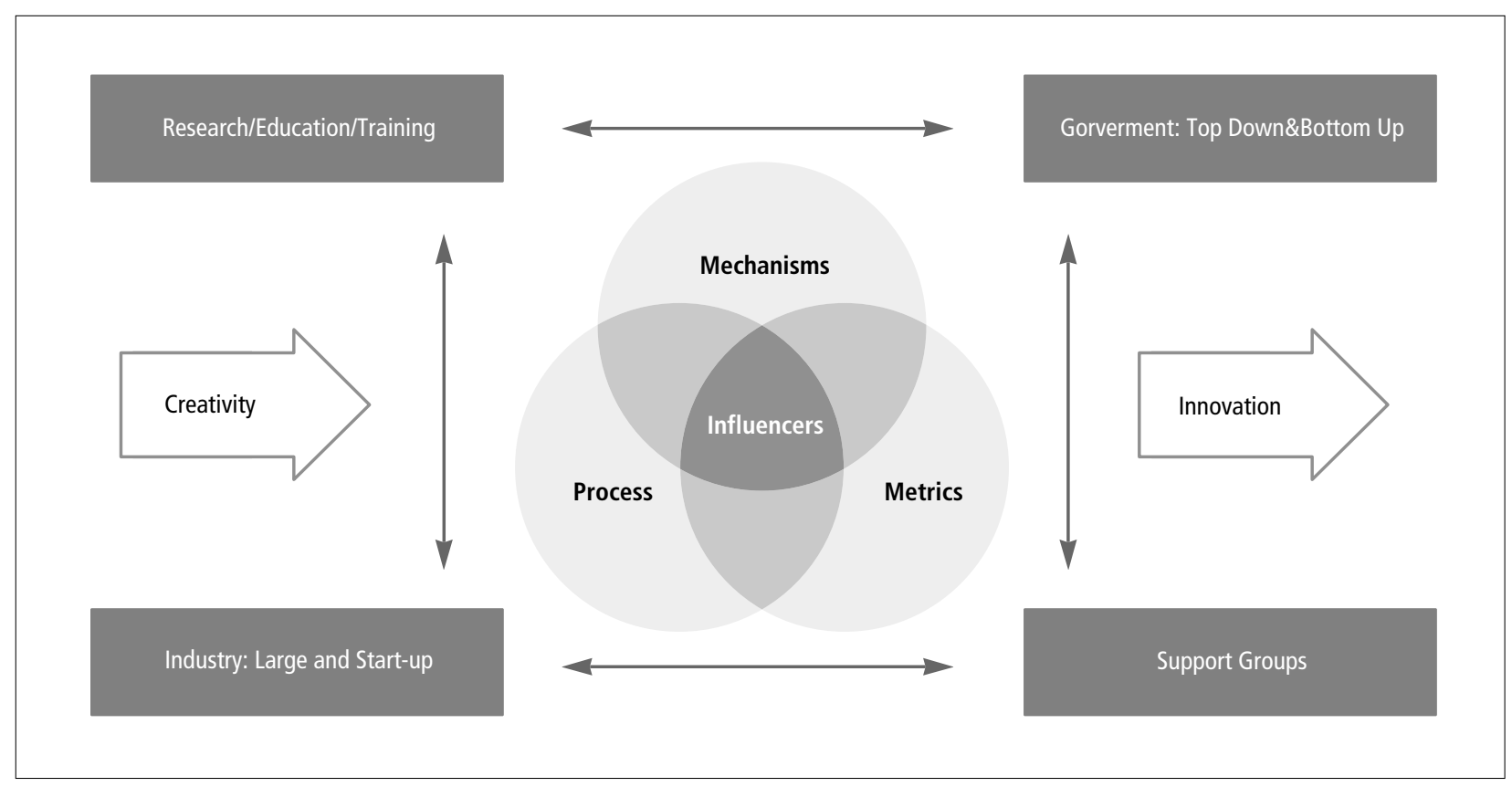

Fig. 1. A Countinuing Regional Challeng Worldwide

Source: $\mathrm{IC}^{2}$ Institute, The University of Texas at Austin

\subsection{The Key Role of Influencers}

There are many regions in the US with excellent research universities, proactive city governments and chambers of commerce, and a highly-touted quality of life that have not been very successful in leveraging these assets for accelerated technology-based regional development. In "Creating the Technopolis: High Technology Development in Austin Texas," (1988) the authors stressed the key role of $1^{\text {st }}$ and $2^{\text {nd }}$ level influencers who networked across academic, business, government, and support groups sectors to envision and enact important economic development policies and strategies. A main conclusion of the current research is that the "momentum" for successful regional cooperative activity in Austin, Texas has continued to come from key influencers visionaries and champions - within and working across sectors or sub-sectors to connect and leverage otherwise unconnected and perhaps competing actors for a common purpose through formal and informal collaboration, coordi- 
nation, cooperation and at times synergy during key targets of opportunity (Phillips 2008). ${ }^{1}$ The focus is on influencers and the networks in which they are embedded as opinion leaders and as communication bridges (Rogers and Kincaid 1981).

$1^{\text {st }}$ level influencers are usually successful leaders in "their" sector, but they also maintain extensive personal and professional links to other sectors and they effectively cross sectors with credibility and influence. $1^{\text {st }}$ level influencers also tend to mentor and at times "protect" $2^{\text {nd }}$ level influencers as they work across different public-private sectors to structure and implement action oriented activities that challenge institutionalized rules, procedures, and established expectations of conduct. ${ }^{2}$ Second-level influencers act as informal communication bridges to first-level influencers while initiating boundary-spanning activities with their colleagues and trusted friends in other sectors whether within large institutions like the research university or across business, academia, or government. The personal communication networks of such influencers tend to be outward looking and open as opposed to being closed and provincial and such "outward looking" networks tend to be multidisciplinary and international. Social Network researchers look to the individual's social environment for explanations, whether through influence or leveraging processes, on how certain things get done because of the connections one has to others (Borgatti, et.al. 2009).

\section{THE UNIVERSITY OF TEXAS AT AUSTIN}

This paper supports the view that a research university's most important deliverable for industry and society is to graduate educated students. With a 2013 enrollment of about 38,500 undergraduate and 11,500 graduate students, UT Austin is a major supplier of educated talent for regional, as well as national and global, industry and academia as well as the public sector. ${ }^{3}$ Following in order of relative importance, after the number-one priority of graduating educated students, Austin's industry's top needs from the university are reported to be: Continuing education opportunities; consortia and research centers; consulting; and sponsored research followed by intellectual property (IP) and technology licensing. ${ }^{4}$ UT-Austin is considered the keystone institution for fostering technology-based growth through: (1) The achievement of scientific preeminence, (2) the development of new technologies for emerging industries, and (3) the attraction of major technology companies and the creation of home-grown technologycompanies. In the regard we describe three key aspects of UT-Austin that have been crucial to the growth and sustainability of the Austin Technopolis: (1) endowed research chairs, (2) research and development (R\&D) expenditures, and (3) enhanced technology licensing and spinoff activity including the University's Austin Technology Incubator and the growth of entrepreneurship programs and activities across a broad range of University colleges and departments.

\subsection{Endowed Chairs}

Endowed chairs help attract top researchers who are key to winning competitive state, federal, and international research grants that fund fellowships and attract superior graduate students. The resulting outcome is a clustering of established and emerging talent in centers of research and

\footnotetext{
1 "Collaborate" means to cooperate with the enemy. "Coordinate" means to bring into proper order or relation; to harmonize; to adjust. "Cooperate" means to act or work together with others for a common purpose; to combine in producing an effect. "Synergy" is the simultaneous action of separate agencies which together have a greater total effect that the sum of their individual effects. (Webster's New World Dictionary; Gibson and Rogers 1994)

${ }^{2}$ Such a first-level influencer was Dr. George Kozmetsky, co-founder of Teledyne who was recruited to Austin in 1966 as the Dean of UT's College of Business Administration. Dr. Kozmetsky is considered an early visionary of the Austin Technopolis. He founded and initially funded the IC ${ }^{2}$ (Innovation Creativity Capital) Institute at UT Austin in 1977. He became an important influencer and champion for building regional academic-industry-government alliances. He was a key mentor to Austin-based entrepreneurs like Michael Dell; Jim Truchard of National Instruments; John Mackey of Whole Foods; and hundreds of entrepreneurs at home and abroad. Kozmetsky was a key catalyst in developing Austin's strategy for winning the MCC in 1983 and in championing such regional catalytic organizations as The Austin Technology Incubator and The Capital Network in 1989 and The Austin Software Council in 1991. In 1993, George Kozmetsky received the National Medal of Technology from President Clinton.

${ }^{3}$ The University of Texas at Austin, established in 1863, is the flagship campus for the UT-System which is comprised of 9 universities and 6 health institutions. UT Austin enrolls about 50,000 students/year with 18 colleges and schools and 86 doctoral programs. The Cockrell School of Engineering's has 267 faculty and more than 7,800 students enrolled in nine undergraduate and 13 graduate degree programs. The College of Natural Sciences has 370 faculty and 10,800 students and 37 research units.

${ }^{4}$ Bill Catlett, Office of Industry Engagement, The University of Texas at Austin and cited in Corporate Relations Functions at the Nation's Leading Research Universities, Tim Mulcahy, University of Minnesota, 2007).
} 
education excellence and rising prestige for a university. Competition is intense among research universities worldwide to recruit the best and the brightest professors and students. At UT-Austin endowed chairs help recruit and retain these highly ranked "star" professors as well as top graduate students.

There was a dramatic rise in the number of endowed chairs at UT-Austin in 1982 (32 Chairs) and 1983 (41 Chairs) which was directly linked to Austin's winning the Microelectronics and Computer Technology Corporation (MCC) in 1983. ${ }^{5}$ The dramatic rise in UT Endowed Chairs from under 50 pre-1982 to over 300 in 2012 resulted, in large part, from private donations that were enhanced by UT Austin's matching program. ${ }^{6}$ By 1986 UT Austin's Department of Computer Science was receiving three times as many graduate student applications (about 700/year) as they had prior to 1983 and the Department was admitting candidates with substantially higher Graduate Record Exam (GRE) scores. <Fig. 2> illustrates that as of 2010 the vast majority of UT endowed chairs exist in the College of Engineering (19\%); School of Law (16\%); College of Natural Sciences (15\%); College of Liberal Arts (12\%); College of Business (11\%); and Geosciences (4\%).

In August 2004, The University of Texas System Board of Regents approved $\$ 32$ million funding from the Permanent University Fund to be awarded to System Institutions to help attract and retain highly qualified faculty. The resulting STARS (Science and Technology Acquisition and Retention) program provides funding to help purchase state-of-the-art research equipment and laboratory renovations to help retain STAR faculty in UT-System institutions. The program evolved and expanded in 2005 to include additional support for faculty retention, research, and teaching. For example, in 2010 under the STAR program, UT Austin recognized 34 faculty member recipients for outstanding teaching at the undergraduate level. As a research-to-commercialization oriented example, two UT Austin "star" faculty founded

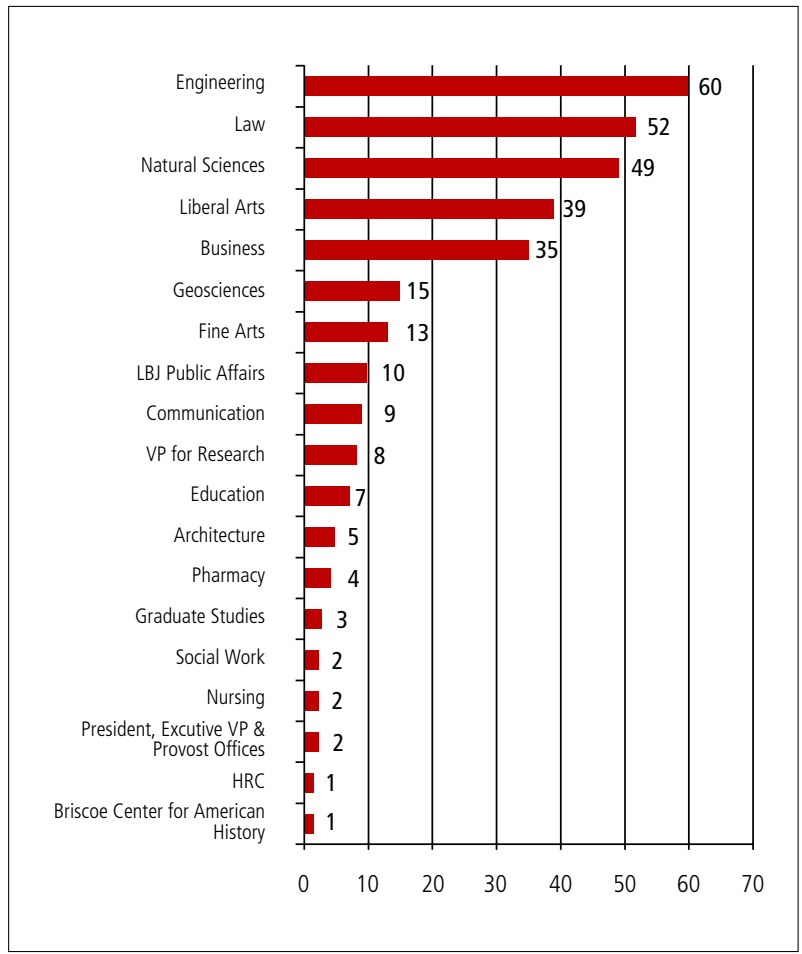

Fig. 2. UT Austin Endowed Chairs by Academic Unit (Total 317, as of 12/21/2010)

Source: The University of Texas at Austin

Molecular Imprints with $\$ 3$ million support from State of Texas Emerging Technology Research Fund. This research built on Cockrell School of Engineering patented ink-jet technology with a revamped manufacturing process known as "ink-jet roll-to-roll nano-patterning" in order to produce large, inexpensive manufacturing tools needed for electronic devices and photovoltaics.

A different Science and Technology Affiliates for Research (STAR) Program at UT Austin was launched in 2012 by the Texas Advanced Computing Center (TACC) and offers supercomputing, advanced visualization, grid computing, and massive scientific data management to benefit both science

\footnotetext{
5 The Microelectronics Computer and Technology Consortium (MCC) located in Austin, Texas in 1983 after a major national promotion and competition. MCC was the first for-profit R\&D consortium in the US and motivated the passage of the National Cooperative Research Act of 1983. MCC was a key and early catalyst for Austin's rise as a globally competitive technopolis.

${ }^{6}$ Winning the MCC provides an excellent example of public and private sector synergy at the regional level while strengthening UT Austin as a top research university. Peter O'Donnell, a successful Dallas businessman arranged with UT administrators to leverage his $\$ 8$ million gift for endowed chairs with an additional $\$ 8$ million from the private sector which was matched with $\$ 16$ million from the University of Texas Permanent University Fund (PUF) to create, in 1983 , $\$ 32$ million chairs in computer science and engineering. The Permanent University Fund (PUF) is a Sovereign Wealth Fund with total assets of about \$14 billion as of December 2012 . The PUF was created by the State of Texas in 1876 to fund public higher education. A portion of the returns from the PUF are annually directed towards the Available University Fund (AUF).
} 
and business. For example, Aramco Services Company, a Houston-based affiliate of the Saudi Arabian state oil company, used STAR to remotely execute a billion cell mesh visualization of an oil reservoir. The TACC-STAR Program is currently expanding into undergraduate and PhD-level computational education to better fulfill growing industry needs.

\subsection{Research Funding}

UT Austin research expenditures grew from $\$ 376$ million (FY02-03) to $\$ 589$ million (FY 10-11) significantly up from $\$ 120$ million in 1986 . $^{7}$ During 2010-2011, federal government funding to UT Austin totaled $\$ 355.5$ million and the main funding agencies were Department of Defense (DOD) at $\$ 122$ million; National Science Foundation (NSF) at $\$ 76.5$ million; Health and Human Services (HHS) at $\$ 72$ million; Department of Energy (DOE) at $\$ 42.5$ million; and National Aeronautics and Space Administration (NASA) at $\$ 13$ million. For the same time period, corporate funding to UT
Austin was about $\$ 68$ million; state and local research funding totaled about $\$ 41$ million; non-profits about $\$ 31$ million; and institutional funding at about $\$ 88$ million. As of FY 1011 , research expenditures by academic unit have been $\$ 158$ million for the VP forResearch, ${ }^{8} \$ 146$ million for the College of Natural Sciences, $\$ 130$ million for the College of Engineering, $\$ 56$ million for Geology, and $\$ 30$ million for the College of Education, <Fig. 3>. As of early 2012, UT Austin's Cockrell School of Engineering had 21 science and technology (S\&T) research units with annual budgets greater than one million dollars followed by the College of Natural Sciences with 27 such research units; UT Austin's VP Research with eight units; and the Jackson School of Geology with four research units each with annual funding greater than one million. Twenty-eight research units have annual budgets of greater than $\$ 5$ million.

As an example of UT-Austin research-industry collaboration is the Cockrell School of Engineering's Wireless Networking

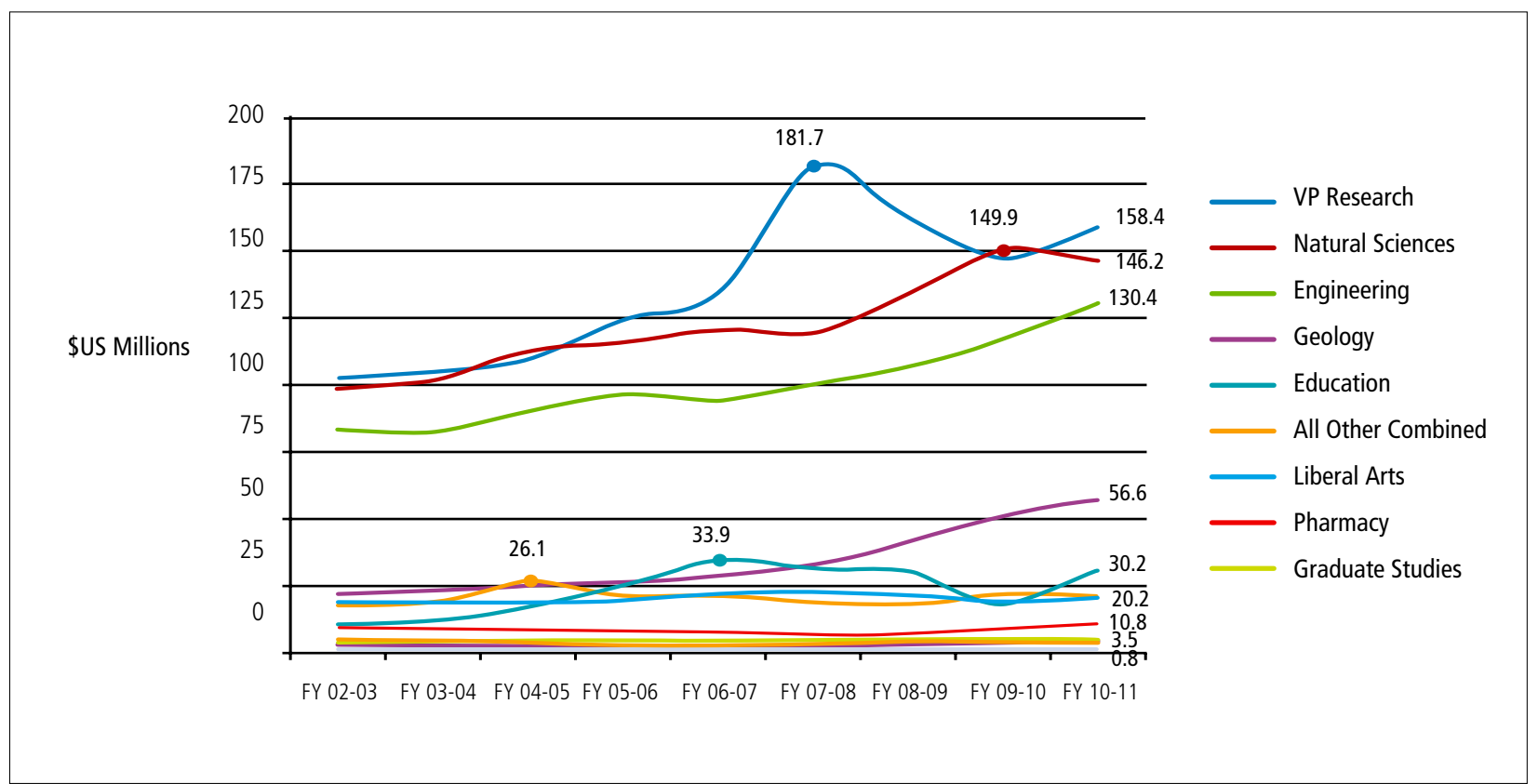

Fig. 3. Total Research Expenditure by Academic Unit and Year (US\$, millions) Source: The University of Texas at Austin

\footnotetext{
7 The total dollar amount of contracts and grants awarded to UT Austin was about $\$ 55$ million in 1977 and increased to about $\$ 120$ million in 1986 . In 1989 Federal funding totaled almost $\$ 90$ million or about $60 \%$ of UT Austin research funding as compared with 7.5\% State grants and 7\% industry funding (Austin TechnologyBased Industry Report, 1991).

8 VP for Research funding includes university activities and programs such as UT Austin's Applied Research Labs (APL), Center for Electromechanics, The Center for Computational Engineering and Sciences, The Texas Advanced Computing Center, and the $\mathrm{IC}^{2}$ Institute.
} 
and Communications Group (WNCG). WNCG's research funding has exceeded $\$ 20$ million since its formation in 2002 with the support of 13 industry affiliates and sponsors. ${ }^{9}$ In 2012 WNCG was named as a prestigious National Science Foundation (NSF) Industry/University Collaborative Research Center (I/UCRC). The award provides WNCG with about $\$ 400,000$ in initial funding over a five-year period. The funding is renewable up to 15 years. The I/UCRC program is an annual competition created by NSF to reward university research centers that demonstrate great promise for research breakthroughs while exhibiting a strong track record of collaboration with companies and other universities. As noted by Dean Gregory L. Fenves, Cockrell School of Engineering,

WNCG is one of the world's leading wireless research centers, involving more than 16 faculty and 120 graduate students in electrical engineering, aerospace engineering and computer science. The crucial support provided by NSF will allow WNCG to accelerate its research on the greatest wireless challenges that society needs to solve in the next several decades." (UT web, "WNCG Awarded NSF Industry Collaboration Center," Wednesday, February 2, 2011)

\subsection{Knowledge Transfer and Commercialization}

UT Austin's Office of Technology Licensing (OTL) was launched in September 1991 and reflecting university concerns of the time the office was staffed by lawyers who emphasized the protection of UT's IP. As a result of increased state political and societal pressure calling for greater economic impact of UT Austin research, more emphasis has been placed on transferring knowledge and technology out of the university and into the marketplace. In brief, the transition of increased emphasis on S\&T commercialization has been a difficult challenge given the established norms and values of a state university funded, in large part, by public money. In September 2003, the OTL was renamed The Office of Technology Commercialization (OTC). While undergoing difficult institutional change, UT Austin's OTC continually works to improve processes for transferring university research to industry including:

- Evaluating, protecting, marketing, and licensing university inventions and software

- Assisting in the formation of startups

- Promoting collaboration with industry, investors and other stakeholders in the technology commercialization

- Informing UT Austin faculty on appropriate and current patent protection and commercialization processes.

Between FY 2003 and 2011 UT Austin was issued 276 US and 148 foreign patents. In FY 2010-2011 34 US patents were issued in the US and 28 in foreign countries with the most foreign patents being filed in Japan followed by Denmark, Sweden, Ireland, the UK, Switzerland, Germany, France, India, and Mexico. Annual tallies of license agreements at UT Austin have ranged from the mid-twenties to a high of 58 in 2008 for a total of 306 license agreements over the past nine years. Licensing income has increased considerably from about $\$ 500,000$ in 1992 to over $\$ 25$ million in 2011. As is common in most university royalty streams, a few patents provide the great percentage of financial rewards.

One of OTC's key responsibilities is to serve as a startup or spinoff catalyst for the University. $<$ Fig. $4>$ shows the number of UT-Austin IP-based Texas and Non-Texas located startups per year from 1990 to 2011. There have been 58 spinoffs based on UT Austin research since 2003 with a high of 13 spinoffs in $2010 .{ }^{10}$ We believe it is also important and correct to include non-IP spinoffs in any assessment of the economic development impact of a research university. For example, in Austin, it is important to include university connected companies such as National Instruments and DELL Corporation in the UT affiliated spinoff category as it was UT Austin that brought the founding entrepreneurs to Austin: Jim Truchard and colleagues launched National Instruments while working at UT's Applied Research Labs (ARL) in 1976 and Michael Dell launched his entrepreneurial effort as an undergraduate business student in 1984 It is also noteworthy

\footnotetext{
${ }^{9}$ These sponsors are: AT\&T, Cisco Systems, U.S. Department of Defense, Panasonic, Yokogawa, Powerwave Technologies, Commscope Corp., Samsung, National Instruments, Dell, Qualcomm, Texas Instruments, and Huawei, who participate as Industrial Affiliate members, as well as major government support from the Army Research Laboratory, NSF and the Defense Advanced Research Projects Agency.

${ }^{10}$ A university spin-off is considered to be a company that licenses a technology from a university in order to function; that is, the company did not exist until the time the university technology was licensed. A company is considered a spin-off regardless of whether or not the company founders were involved in the creation of the licensed technology.
} 
that these entrepreneurs chose to grow their companies in Austin, in part, because of the region's quality of life which they and their colleagues and employees and their families enjoyed and because of the critical importance of having a continuing supply of qualified talent graduating from UT Austin and other regional education institutions. In addition, we argue that UT Austin also deserves considerable credit for the founding of non-technology Austin-based entrepreneurial enterprises such as Whole Foods, Inc. and the SXSW Interactive Film and Music Festivals as both were founded by former UT Austin students and have been supported in their local growth by UT students and graduates as employees and as customers.

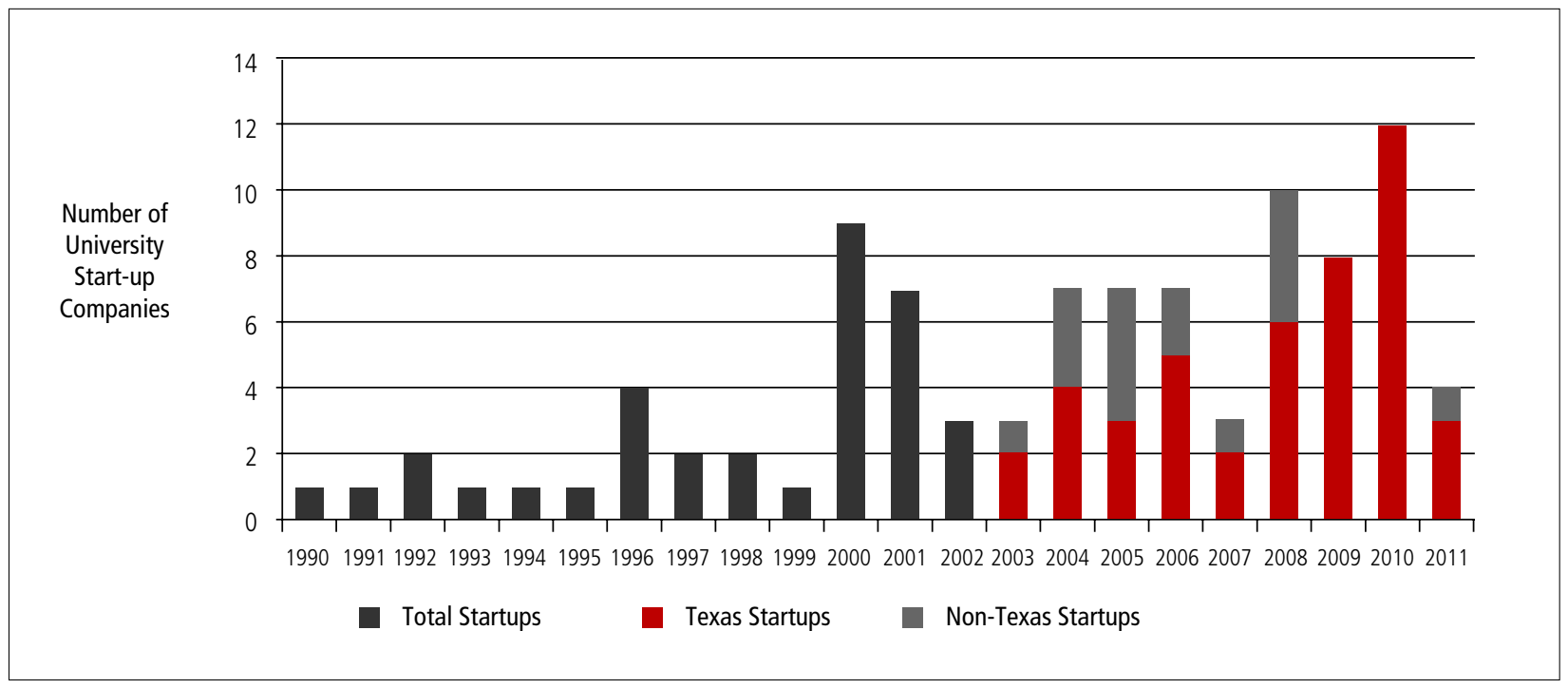

Fig. 4. Number of UT-Austin IP-Based Spinoffs by Year, 1990-2011

Source: Texas Higher Education Coordinating Boards, 1990 through 2003; OTC 2003 through 2011.

\subsection{The Austin Technology Incubator}

Beginning operations in 1989, The Austin Technology Incubator (ATI) at UT Austin has been a key catalyst in developing Austin's entrepreneurial and innovation ecosystems continuing into 2013. In 1989, Austin was in an economic slump and "see through" buildings were prevalent. ${ }^{11}$ Led by the $\mathrm{IC}^{2}$ Institute, the Austin Technology Incubator "experiment" secured modest 3-year funding of $\$ 50,000 /$ year from the City of Austin and $\$ 25,000$ /year from The Greater Austin
Chamber of Commerce and a onetime donation of $\$ 70,000$ from Travis County plus $\$ 50,000$ from a private donor. ATI was launched near the epicenter of emerging software technology companies, in 4,000 sq. ft. of "borrowed" office space with donated furniture from university storage and an Austin retail store with some "difficult to sell" furniture. ${ }^{12}$ University administration was not entirely comfortable with the idea of a state supported educational institution hosting a business incubator, even if it was not-for-profit, so the concept was

\footnotetext{
${ }^{11}$ In 1982 Austin had 16 million sq. ft. of office space and the occupancy rate was $95 \%$. In part motivated by the economic development hype of winning the MCC headquarters, by 1986, 14 million sq. ft. of office space had been constructed and the occupancy rate had dropped to $70 \%$ and by mid-1987 an additional 6 million sq. ft. dropped the office occupancy to $60 \%$ (Gibson and Rogers, 1994). In 2012 Austin's vacancy rate is at $17 \%$ and leases are being signed at $32 \%$ over 2011 prices (Forbes Web, May, 2012).

12 As one of the wealthiest Texans, Dr. George Kozmetsky could have simply underwritten the start-up expenses of ATI; however, he wanted to secure buy-in and commitment from key public and private stakeholders and he wanted to emphasize building an entrepreneurial start-up culture as being most important to the launch and sustained success in the management and operation of the Austin Technology Incubator. As an additional challenge to the launch of ATI, a previously launched and well-funded Austin-based technology incubator called Rubicon had closed its doors with no successful graduate companies and millions in lost investment.
} 
"presented" as a technology venturing laboratory for UT students and professors much like a chemistry or physics lab.

In 1989 the lack of venture or angel capital was a noted challenge for the successful operation of ATI and the growth of a regional entrepreneurial culture. Recognizing this need, the IC $^{2}$ Institute launched the Texas Capital Network (TCN) as a non-profit angel fund that matched promising ventures to potential investors. TCN was built on the participation of wealthy influencers state-wide who agreed to review business plans in technology sectors that they were interested in, and if they so desired, provide seed funding to a particular entrepreneurial venture. TCN, which was based at ATI, was renamed The Capital Network and grew to be the largest angel fund in the Southwest, facilitating more than $\$ 150$ million in total investments with 2000 registered entrepreneurs. TCN's annual Venture Capital Conference regularly attracted upwards of 300-500 investors and entrepreneurs who came from across the nation and internationally to hear venture pitches from Texas start-ups. As VC and business angel groups became more prevalent in the Austin region, TCN terminated operations in 2001. ATI and TCN and the Austin Software Council which IC $^{2}$ founded in 1993 were key catalysts in building Austin's emerging innovation ecosystem by conducting training seminars on business plan development, deal structuring, managing the investment process, and by organizing venture competitions.

Since its inception ATI has had the dual purpose of service to the University as an education and research laboratory on entrepreneurship and technology venturing and as a regional catalyst for economic development. Over the years, as Austin's regional innovation and entrepreneurial support systems have grown and matured, so has ATI. Austin's current entrepreneurial ecosystem has a broad range of private and public support structures and associations supporting technology venturing, consequently ATI incubation activities have focused on providing high value mentoring in four technology verticals: IT, clean energy, wireless, and biosciences. ATI brings to its portfolio of companies, in each industry sector, deep domain management expertise and investor network access. It is important to note that each of these industry verticals has important formal and informal links to UT Austin research and education as well as to city and chamber of commerce economic development objectives. In brief, ATI has been central to assisting entrepreneurs with building successful business teams to support technology ventures and to better access angel, VC, and state funding; mentoring students from across campus; mobilizing the regional business community around emerging technology sectors; and graduating high-growth ventures into the Austin community. With active support from local business professionals and the chamber of commerce, city government, and the University for 25 years, ATI has maintained a well-earned reputation as of one of the nation's finest examples or models for technology business incubation. $^{13}$

\subsection{UT Austin's Growing Entrepreneurial Fever}

Starting in 1977 with the founding of the IC $^{2}$ (Innovation, Creativity, Capital) Institute at The University of Texas at Austin entrepreneurship teaching, competitions, and other activities have grown campus-wide from the Moot Corp Competition for entrepreneurs established in the Business School in 1984 and the Chair of Free Enterprise established in the College of Engineering in 1985 to an explosion of campus-wide programs and classes on entrepreneurship continuing into 2013, <Fig. 5>. To highlight the increasing importance of fostering the entrepreneurial experience in university environments, in February 2012, the UT System issued a call for proposals for Novel Programs in Education for Innovation and Entrepreneurship. As stated,

There is an emerging call for research universities to serve as entrepreneurial centers that drive research breakthroughs and discover solutions to large-scale scientific and social problems $\cdots \cdots$ many argue that innovation and entrepreneurial activity must grow exponentially if we are to continue to advance American science and technology. The institutions of the UT-System are an ideal ground from which to advance a highly-visible, cross-institutional culture that fosters entrepreneurship rather than entrenched "silo" thinking. To accomplish such goals, fresh, new methodologies must be developed that will advance

\footnotetext{
${ }_{13}^{13}$ Since its founding in 1989, ATI has graduated over 150 companies; raised more than $\$ 720$ million; had 4 IPOs; 25 acquisitions; created an estimate of over 10,000 direct and indirect jobs; and trained hundreds of UT-Austin students from a range of UT colleges and departments. Capital raised by ATI member companies and alumni in recent years totaled $\$ 111,571,479$ in 2011 and $\$ 103,918,000$ in 2012. Overall the estimate of capital raised by ATI since 1989 is $\$ 1,081,186,000$.
} 


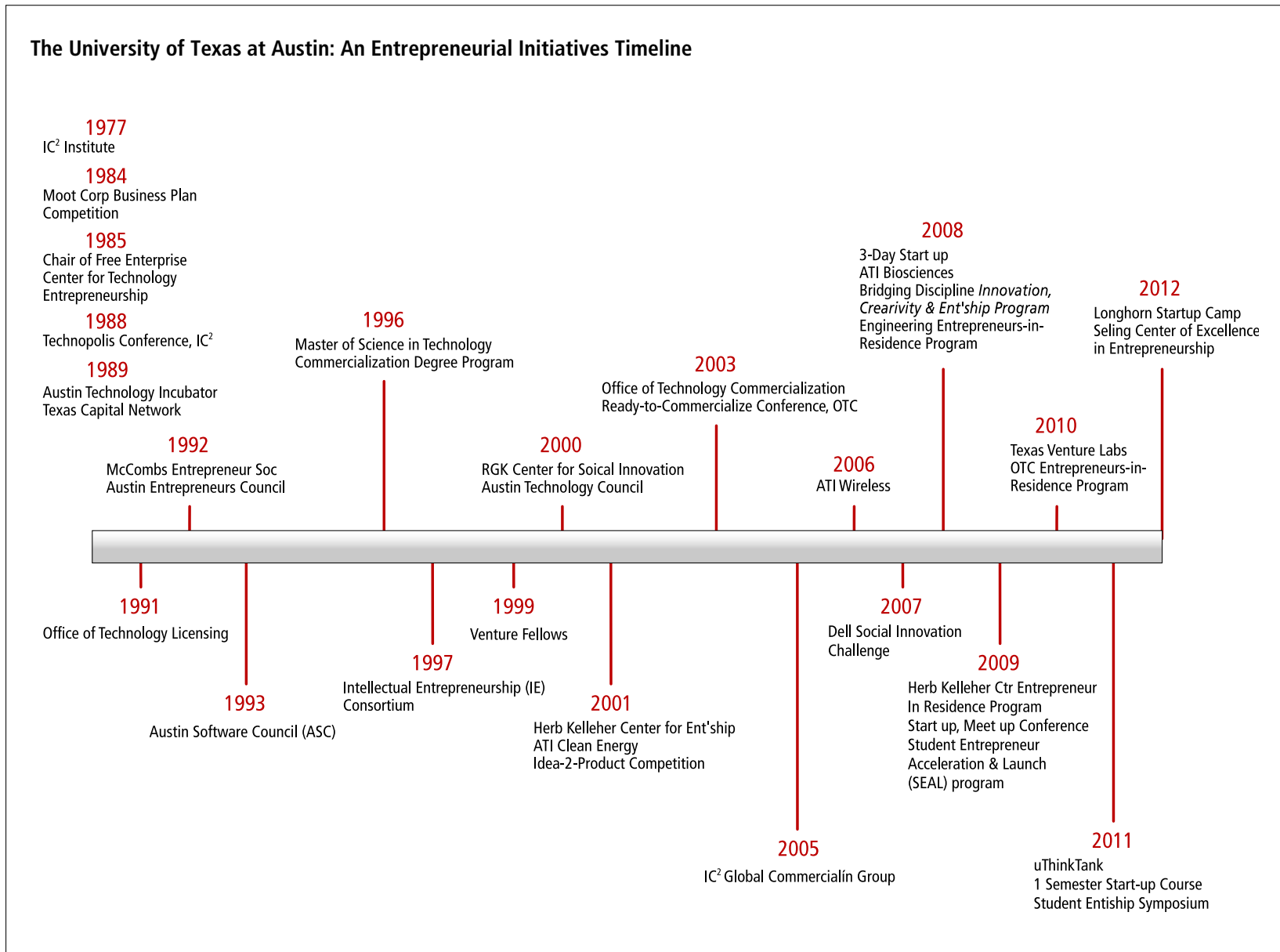

Fig. 5. Timeline of Entrepreneurial and Technology Transfer Initiatives at The University of Texas at Austin

the education of established and budding scientists and train research leaders who are facile in forming academic-industry partnerships and creating companies and enterprises.

Thinking and acting entrepreneurially in academia, business, and government in for-profit and not-for-profit activities and in fostering innovative environments are seen as good things. But one should be careful of the metrics used to measure the success of such programs. In the end, the success and growth of any entrepreneurial venture depends heavily on the innovation ecosystem in which it is embedded. While many of Austin's current role models (such as Michael Dell, Jim Truchard of National Instruments, or John Mackey of Whole Foods Inc.) launched their enterprises without such formal institutional support, they benefited in centrally important ways from key Austin academic and business mentors and influencers.

\section{THE INDUSTRY SECTOR}

Successfully recruiting, retaining and growing, and creating firms in one or more globally competitive industry sectors or clusters is perhaps the most important indicator of a successful innovation ecosystem. We suggest that there are four main strategies of regional technology-based growth: firm recruitment, firm retention and expansion, new firm and industry sector development, and newer institutional alliances and partnerships, <Fig. 6>. The University of Texas at Austin has been a central and important asset to each of these strategies. 


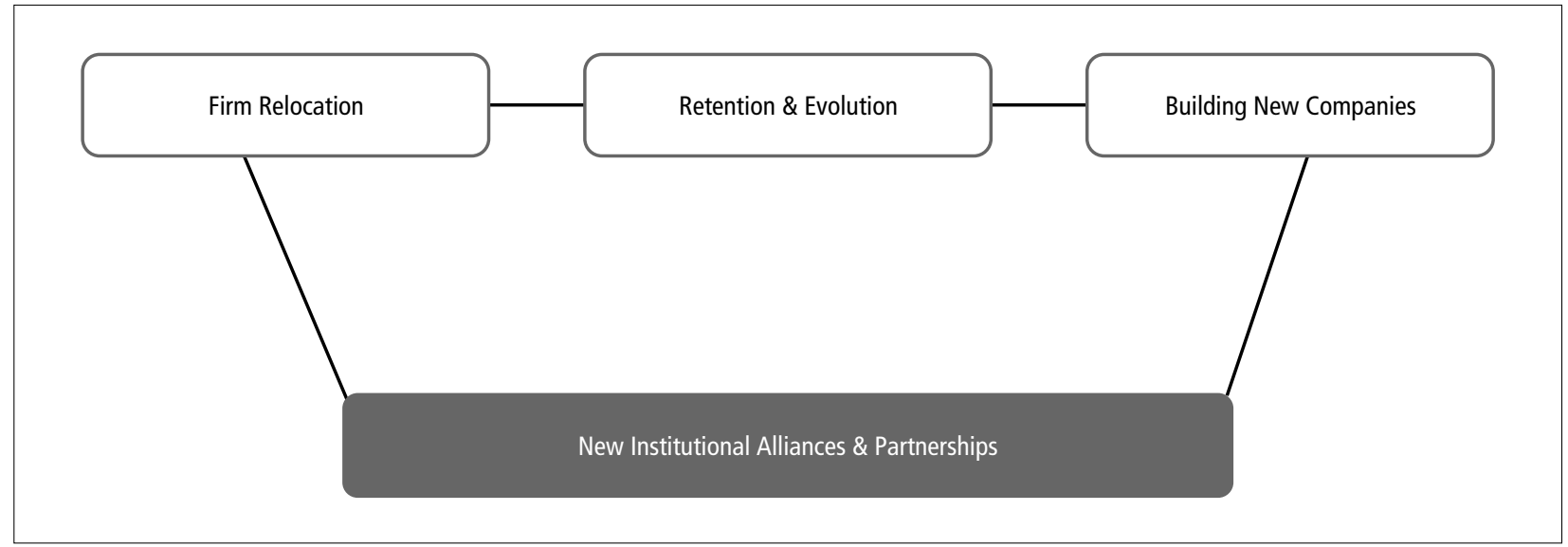

Fig. 6. Four Strategies for Regional Technology-Based Development Source: IC Institute, The University of Texas at Austin

In 1984, the public-private collaboration effort led by the "MCC location Team" of government, business and academic influencers successfully recruited $3 \mathrm{M} R \& D$ operations from Minnesota to Austin and four years later led the successful bid for Sematech, the nation's preeminent semiconductor R\&D consortium, followed by Applied Materials in 1992, and Samsung in 2005. Austin's development unfolded over time as large and small software, semiconductor, and PC companies located in Austin in what may best be described as a snowball effect-as more companies located in the Capitol City more were attracted to the region. The recruitment of businesses and the founding of Austin-based firms fueled the region's development by providing high value jobs and careers, discretionary income, and taxes while branding Austin as a technology region capable of competing with national and international technology centers.

\subsection{A Regional Challenge}

In 2007, given the considerable downsizing of Austinbased semiconductor manufacturing as a result of increased global competition, it was clear to business and community leaders that the region should not base its future job and wealth creation so heavily on this one industry sector. Furthermore it was also clear that Austin's PC Industry, i.e. DELL Corporation, would not be the main accelerator for job and wealth creation that it had been in the 1990s. The regional challenge was how to leverage Central Texas' considerable assets in fabrication facilities and experienced talent and trained workers to the benefit of emerging industry sectors. In response to these challenges, the City and the
Greater Austin Chamber of Commerce worked together to target the following seven industries for recruitment and entrepreneurial support: Automotive and Aerospace research and components manufacturing; convergent technology; data centers; life sciences; wireless; clean energy;

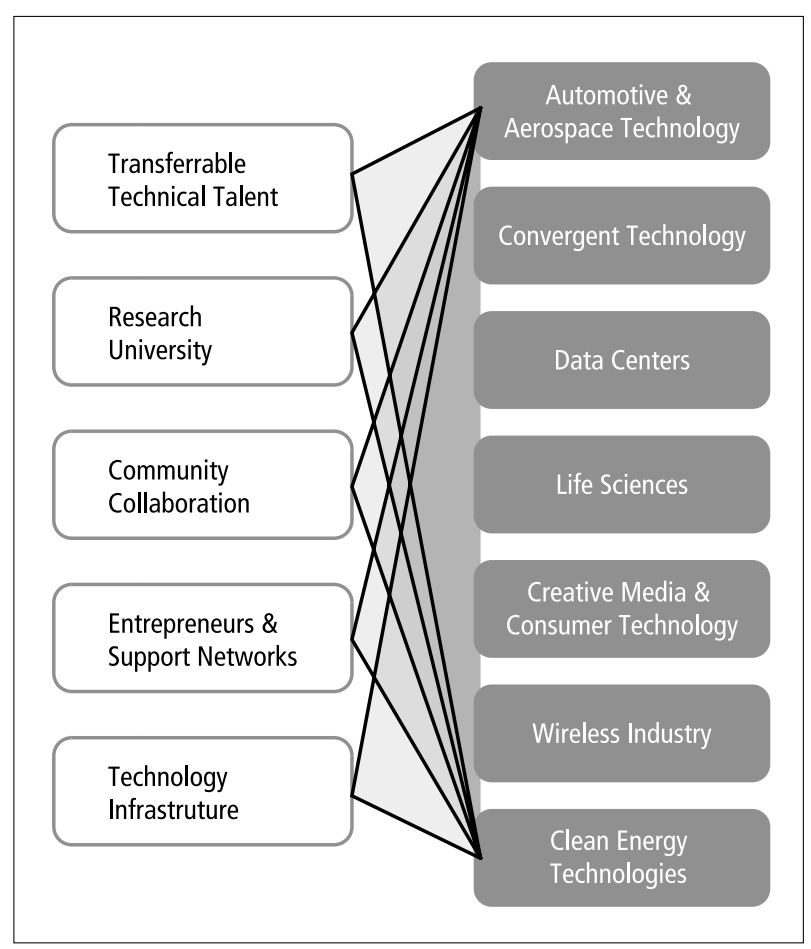

Fig. 7. UT Austin's Assets Supporting High Tech Industries \& Targeted Industry Start-ups

Source: Powers 2004 
and creative industries and multimedia, $<$ Fig. $7>$. It is important to note that each of these industry sectors had an established and growing Austin presence including relevant research, education, and training programs at the University of Texas and other regional universities and colleges.

In addition to firm relocation and technology venturing, firm retention and growth is important to regional economic development and sustainability. For example, initially attracted by Texas' lack of corporate and personal income tax, cheap land, and a relatively low cost of living IBM came to Austin in 1966 to manufacture the electric typewriter. More importantly, IBM elected to stay in Austin and transition into a major research center. From the creation of the world's fastest UNIX servers and the groundbreaking Cell Processor, IBM Austin has evolved as a critical component of IBM's globally integrated enterprise and is recognized as one of IBM's eight main research laboratories worldwide. The Austin research facility was created in 1995 to explore the usage and expansion of microprocessor research through the growing technology market of high-speed microprocessors with an emphasis on very fast circuits and computer- aided design tools to support complex, high performance microarchitectures. More recently IBM Austin research includes software and hardware systems, high-speed communication chips, formal verification, distributed systems software, innovative cooling technologies, low power microprocessors, systems management, and performance evaluation. IBM and UT Austin have partnered to build substantial education and research programs while working with the City and The Greater Austin Chamber of Commerce to help shape the region's technologylandscape. ${ }^{14}$ With more than 6,239 employees and an annual payroll of about $\$ 600$ million, IBM Austin is the largest corporate R\&D operation in Texas. In 2008, IBM received 4,186 US patents, the most of any US company. IBM-Austin contributed 825 patents to the total, more than any other IBM location worldwide. ${ }^{15}$ As noted by Ben Streetman, Former Dean of UT Austin's Cockrell School of Engineering,

Through the sharing of technology, resources, and talent, IBM and The University of Texas have enjoyed mutually beneficial relationship that goes back many

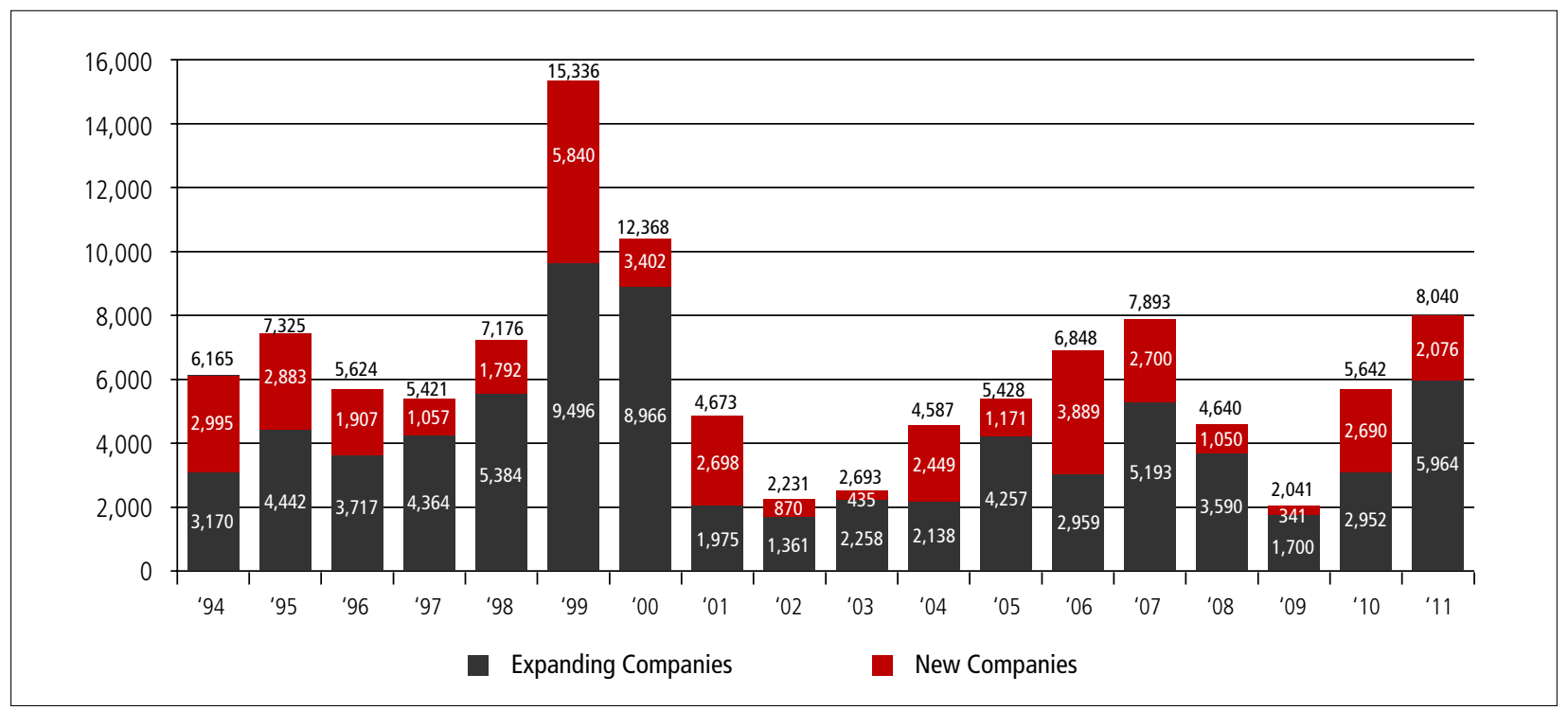

Fig. 8. Austin Jobs Created by New Company Creation \& Company Expansion, 1994-2011 Source: Greater Austin Chamber of Commerce

\footnotetext{
14 Forbes in their first-ever ranking dubbed "The Silicon Hills" of Austin as America's $2^{\text {nd }}$ most innovative city after Silicon Valley, CA. The ranking was based on the 100 largest metropolitan statistical areas in the US using data from the US Patent and Trademark Office combined with venture capital investment per capita alongwith ratios of high-tech science and "creative" jobs. Greenburg, Andy, "Americas Most Innovative Cities," Forbes.com, April 24, 2010.

15 About 3,050 patents were issued to Austin area inventors per year in 2010 and in 2011 (US Patent and Trademark Office).
} 
years. IBM is a top hirer of UT engineering graduates year after year. We consider IBM an invaluable partner. (IBM Press Release, October 3, 2007).

$<$ Fig. $8>$ shows the number of jobs created by Austin's new and expanding Hi Tech and Non-Hi Tech companies from 1994 to 2011. Over this 17 year period, Hi Tech company growth created the most jobs in Austin (56,101 or 49\%) followed by the growth of Non-Hi Tech companies $(26,470$ or $23 \%$ ), followed by new Hi Tech company formations $(17,775$ or $16 \%)$ followed by new Non-Hi Tech companies $(13,775$ or $12 \%) .{ }^{16}$ Clearly, while start-up and entrepreneurial ventures are important, the retention and expansion of existing firms is a key regional job and wealth creation strategy.

As of 2011 Austin's technology company employment totals about 101,000 in the following industry sectors: High tech information and other IT 32,000; high tech manufacturing 28,000; creative media 26,000 (employed in 2,160 firms); computers and electronics 24,000; engineering, R\&D and labs/testing 19,000; and semiconductors 12,000. Dell with 14,000 employees tops the list of Austin's largest technology company employer followed by IBM with 6,239; Freescale Semiconductor with 4,336; AT\&T 3,450; Advanced Micro Devices 2,933; National Instruments 2,500, Apple 2,500; Applied Materials 2,500; Flextronics 2,113; and Samsung Semiconductor 2,000 .

\section{GOVERNMENT SECTORS}

In the US, the government segments can be usefully identified at three levels of analysis: federal, state, and city government. Each of these sectors can contribute to or frustrate regional strategies for technology-based growth.

\subsection{Federal Government}

The influence of the federal government on Austin as well as other technology-based regions in the US has been largely manifested in policy initiatives such as the Bayh Dole Act of
1980, funding for university-based research (e.g., NSF, NIH, DoD), and most recently improving national capability for retaining international talent educated in the US through improved immigration and visa procedures. Federal Government policies have also had major indirect impact on Austin's development as exemplified with the transition of a WW II magnesium plant in North Austin to a university research park. In 1949, with the assistance of thenCongressman Lyndon B. Johnson, UT-Austin purchased the site for an off-campus research center that in 1953 became the University's Balcones Research Center and home to Applied Research Laboratories. In 1994 the center was renamed The JJ Pickle Research Campus (PRC) in fond memory and recognition of US Congressman and UT alumnus, J.J. Pickle. The PRC is a collaborative effort of government, industry and academia in science and engineering research and development. The PRC is home to 19 UT Austin affiliated research centers including Applied Research Laboratories, Bureau of Economic Geology, Center for Energy and Environmental Resources, Microelectronics Research Center, Robotics Research Group, Texas Advanced Computing Center (TACC), and the Institute for Geophysics. All of these research centers have benefitted from federal and state research funding.

\subsection{State Government}

Low taxes and no personal income tax and a generally probusiness environment have been touted as key to Texas economic development. However, specific state sponsored economic development initiatives have been key to Austin's growth as a Technopolis. For example, in 2003 the $78^{\text {th }}$ Legislature enacted an economic development plan that included taking $\$ 390$ million from the state's Economic Stabilization Fund (also known as the Rainy Day Account) to create a Texas Enterprise Fund (TEF), to help attract industry to Texas and to create jobs. TEF projects must be approved by the governor, lieutenant governor and speaker of the House. ${ }^{17}$ The TEF was re-appropriated funding in

\footnotetext{
16 Data were extrapolated from longitudinal datasets provided by The Greater Austin Chamber of Commerce. High technology companies were selected according to the following parameters: R\&D and manufacturing in IT, software, and semiconductors; precision parts and applications (i.e. semi-conductors and medical devices); clean energy companies (but not fossil fuel energy companies); business-to-business high tech products and services; b2b and b2c internet or technology infrastructure services. Default, and therefore error margin, falls toward the non-technical or "other" categories.

17 The Fund grants discretion to the Governor of Texas when it comes to awards and this has drawn criticism from Texans for Public Justice among others while advocates call the Fund "a deal closer." Companies that pass the state's selection criteria are also usually approved for tax and other incentives from city and county levels and school districts if applicable (Brian Gaar, "Fund called a 'deal closer," AAS, 4/22/12: A10-11).
} 
2005, 2007, 2009 and 2011. Clearly, Austin's growth as a major technology center has been enhanced with the use of TEF funds as exemplified in the recruitment of such high profile companies as Facebook in 2010, e-Bay in 2011, and Apple's major expansion in Austin beginning in 2013 as well as retaining companies that were in danger of being recruited away from Austin as was Heliovolt in 2007. To date, the TEF has invested more than $\$ 443.4$ million and, it is argued, closed deals on projects generating more than 62,000 new jobs and more than $\$ 15.4$ billion in capital investment in the state.

As a companion to the TEF, the Emerging Technology Fund (ETF) was created by the 2005 Texas Legislature to provide funding for research, development, and commercialization of emerging technologies. ETF grants have been awarded in the following three areas:

1. Commercialization Awards to help companies take ideas from concept to market

2. Matching Awards to create public-private partnerships leveraging the strengths of universities, federal government grant programs, and industry

3. Research Superiority Acquisition Awards for Texas higher education institutions torecruit the best research talent in the world

By 2012 the ETF had invested $\$ 192$ million in 133 companies which made it the largest seed investor in the State of Texas. Outside investors put three times this amount in the startups which attracted almost $\$ 1.3$ billion in investment. Under the ETF the State also awarded $\$ 178$ million in research grants and other assistance to Texas universities including assistance in the recruitment of 52 "star" researchers and their colleagues. (L. Copelin, "Tech fund deals touted," in AAS, B1-2). As shown in <Fig. $6>$ in Central Texas (the Austin region), the TEF has invested $\$ 34,993,000$ in 25 companies across 11 technology sectors. As required by the TEF, each of these companies has an affiliation with a Texas University. The University of Texas at Austin has research collaborations with 23 of these ETF funded companies.

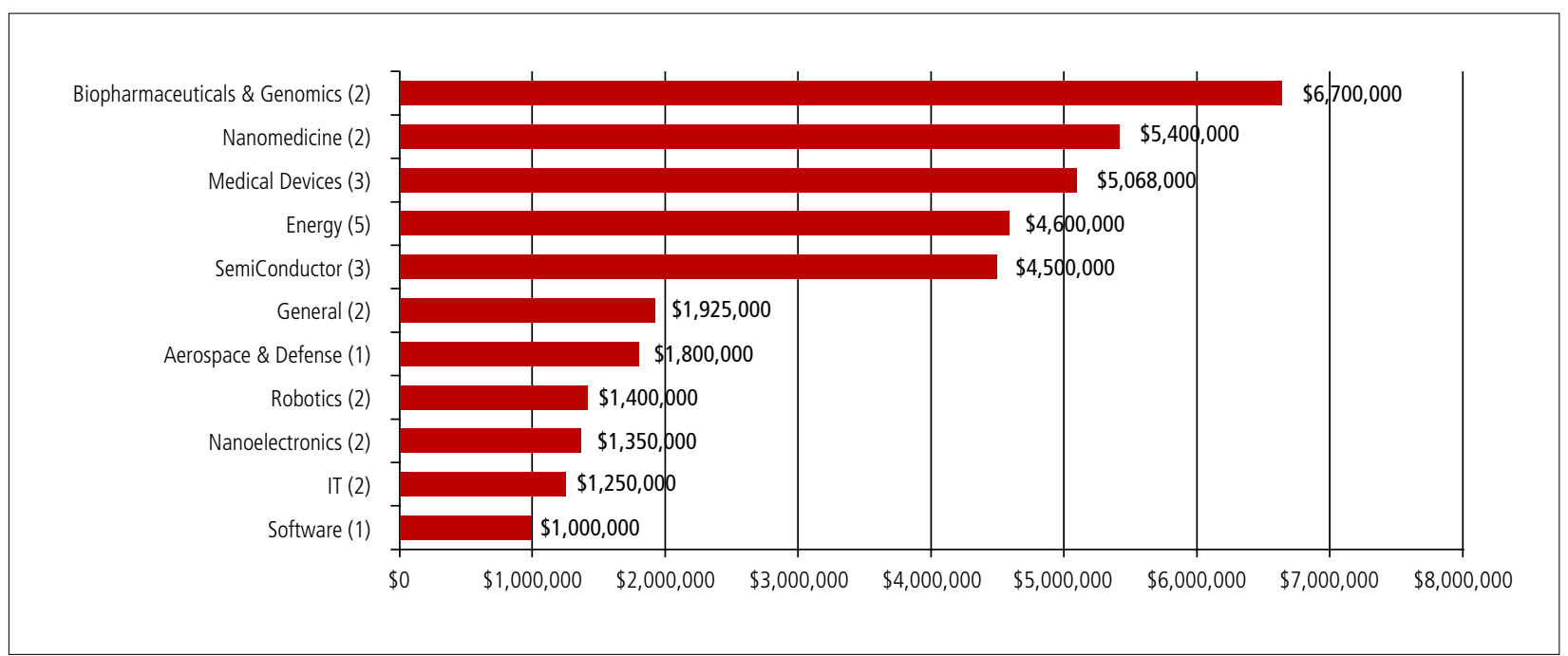

Fig. 9. Central Texas: Texas Emerging Technology Fund Commercialization Investments by Industry Cluster Source: Greater Austin Chamber of Commerce, 2013

\subsection{City Government ${ }^{18}$}

Since 1983, a key challenge in Austin's sustainability as a growing technology region, has been striking a balance between fostering economic development, a rising cost of living, and protecting the regions natural and cultural assets so prized in Austin. Ongoing grievances for tenured

18 Austin's government is comprised of an elected mayor and six council members as well as a City Manager who is appointed by the City Council. 
Austinites and new arrivals include lack of affordable housing, escalating property taxes and utility rate hikes, and increasing traffic congestion. Austin's growth has outstripped the capacity of existing roads and public transport and the citizens are conflicted over options to improve the situation such as light rail. ${ }^{19}$ Austin's City Government has continually worked to maintain the region's attractive, diverse, and accessible quality of life for new arrivals as well as established residents but it has been a continuing challenge. As a result, over the years, mayors and council members have championed actions and policy that impact Austin in different, important, and often conflicting ways.

\subsection{The Importance of Austin's Creative Industry}

Much has been written in recent years about the importance of quality of life and creative enterprise assets in regional development. Richard Florida's The Rise of the Creative Class (2002) documents the environments favored by workers who create ideas, technologies, and content in a variety of fields ranging from science and engineering to arts and music. Such environments foster climates that value diversity and creativity, freedom if economic opportunity, abundant natural amenities, and a thriving urban culture. Given Austin's education assets, green rolling hills, abundant lakes, thriving music scene, and openness to diversity the region exemplifies many quality of life characteristics desired by the "creative class."

Gibson and Rogers (1994) credit Austin's historic music venues and cultural icons for inspiring the free and creative spirit and "Keep Austin Weird" culture. Austin's music scene gained significant momentum in the 1970's as live music artists and venues began to multiply. ${ }^{20}$ The 1976 launch of Austin City Limits at UT Austin's College of Communication TV studio was a seminal event in the city's branding as "Live
Music Capital of the World." After the pilot episode featuring Willie Nelson set fundraising records for Public Broadcasting (PBS), the show was launched by showcasing Texas blues, western swing, progressive country and Tejano music and overtime has included a diverse array of genres including jazz, alternative rock, folk music, and jam bands. In 2003, ACL was awarded the National Medal of Arts. ACL continues as the longest running music show in the history of American television and in early 2011 began its $37^{\text {th }}$ season with the first live performance in the new Moody Theater and studio located in Austin's new W Hotel next to Willie Nelson Blvd. and the Willie Nelson statue in downtown Austin.

As Austin's live music scene developed and was increasingly seen as an integral part of the region's economy, the City Council, in 1991, declared Austin the "Live Music Capital of the World." The City's Parks and Recreation Department lends support by sponsoring musical performances, seasonal events and outdoor concerts that showcase local musicians. The City sponsors annual events that celebrate individuals who have made major contributions to Austin's music and creative environment. In terms of the gaming and digital entertainment industries the City and Chamber work with local educational and workforce development organizations to educate and train a highly skilled workforce for careers in gaming and film. ${ }^{21}$ As of 2013 Austin's digital media industry is the $3^{\text {rd }}$ largest in the US and is a hub for game development across casual, social media, mobile and online platforms. Austin-based IBM, AMD, Freescale, AT\&T, Apple, Facebook, and Google develop hardware, products and services for next generation entertainment and media technologies. Employment in Austin's video game industry has grown from 2,848 employees in 2005 to 7,274 employees in 2010, with an annual economic impact of $\$ 1$ billion.

\footnotetext{
19 "Austin America's Fastest Growing City" (Forbes, web May 2012). Austin's MSA population grew 37\% from 2000 to 2010 as the population growth for Texas was $20.5 \%$ and for the US $8.7 \%$ (US Bureau of the Census). As of 2012 Austin is the $2^{\text {nd }}$ fastest growing US metro area (at $3.9 \%$ ) between April 2010 and July 2011 . Austin Metro area's population is at 1.8 million. Austin's projected growth rate is $2.8 \%$ year almost triple the national rate and is projected to be 2 million by 2015 and to double every 20 years.

20 Threadgill's garage of 1950-60's, in addition to gas and an oil change, also served beer and music while welcoming local and emerging guest artists such as Janis Joplin and a wide sampling of local musicians. Armadillo World Headquarters (1970 - 1980) located in an old National Guard Armory was the iconic venue for established and yet to be established music talent as well as an occasional ballet, poetry reading, and other performing artists. The "dress as you want and come as you are," audience included university professors, students, bikers, cowboys and hippies all sharing the music, Shiner and Lonestar, guacamole and marijuana

21 The Austin Film Society founded Austin Studios in 2000 through a partnership with the City of Austin to lease about 10,000 square feet of production office space in what used to be airplane hangars and office space at the recently closed Robert Mueller Airport. Improvements to the facility include, at 87 feet, the largest cyclorama wall in Texas and two fully soundproofed production stages. Austin Studios goal is to support Austin's film and digital industry including offering areas for set construction, wardrobe, storage, and access to vendors as well as film locations and studios. To strengthen the local film industry the City passed a $\$ 5$ million bond initiative to upgrade the hangers to state-of-the-art soundproof, air conditioned studios with expanded bandwidth and access for digital film production.
} 


\section{SUPPORT GROUPS SECTOR}

While considerably less developed in the mid-1980s than in 2013, the Support Groups sector (e.g., venture and angel capital, chamber of commerce, business professionals and associations) has been critically important to the launch, growth, and sustainability of Austin. Over the years such Support Groups have matured and multiplied in numbers and variety and have become increasingly important in building Austin's regional innovation ecosystem. Business-based support groups include professional services such as law, finance, accounting and related professional associations that foster regional entrepreneurship and innovation. Such groups are an important source of expertise and services for supporting Austin's entrepreneurs, new ventures, and for growing globally-competitive technology-based firms. A key contribution of these groups is providing the business knowhow and to be able to scale select ventures to become major employers with their national and international headquarters based in Austin. Other Support Groups include those representing minority issues, environmental concerns, nonprofits, and community lifestyles. Such groups proliferated as Austin grew. For example, in addition to the formal and informal entrepreneurial support activities resident at UT Austin and other regional colleges, the City of Austin, and the Greater Austin Chamber of Commerce, a 2010 survey found 24 community-based organizations and associations focused on supporting entrepreneurs with 4 of these focused on women entrepreneurs and 3 representing minority groups; 16 groups (not including Austin's established VC and Angel organizations) providing venture funding advice including bootstrapping; 12 community-based education groups and 12 regularly scheduled entrepreneurial events; 6 incubators in addition to The Austin Technology Incubator; and 6 blogs focused on fostering regional entrepreneurship.

\subsection{Civic and Social Entrepreneurs: Giving Back}

An important category of community-based support groups concerns civic- and social-entrepreneurship and philanthropic foundations which are crucial to quality of life activities and are an increasingly important category of support groups integral to Austin's regional development. A good deal of Austin's current philanthropy comes from wealth created successful entrepreneurs who reinvest in their community in terms of social, cultural, and educational initiatives as well as business ventures. The Michael and
Susan Dell Foundation established in 1999 is one of the largest family foundations in the US. Over the years the Foundation has committed $\$ 450$ million to education, health and financial programs with the goal of improving the lives of children living in poverty worldwide. The Foundation gave Austin United Way its first $\$ 1$ million contribution; $\$ 1.9$ million to Austin's Seton Healthcare Network's Insure-a-Kid program to enroll uninsured local children in state- and federally-subsidized health insurance plans; $\$ 25$ million to the DELL Children's Medical Center; $\$ 38$ million to the DELL Pediatric Research Institute; $\$ 3.3$ million to the Austin Independent School District, $\$ 5$ million to the Ronya and George Kozmetsky (RGK) Center for Philanthropy and Community Service, and in early $2013 \$ 50$ million toward building a medical school at the University of Texas at Austin. DELL Corporation's spectacular growth enhanced the wealth of many DELL executives who have remained in Austin after leaving DELL and have continually given back to Austin with time, effort, and money with such important community projects such as The DELL Children's Medical center, The Long Center for the Performing Arts, and the Zachery Scott Theater.

\section{CONCLUSION}

The Austin case has identified key elements that accelerated the creation and supported the sustainable development including visionary leaders; a university with a high level of scientific and technological research; large and small technology companies linked in clusters of activity; supportive government policy especially at the local level; and a broad range of support groups working to sustain a creative and high quality environment. However, institutional excellence in any or all of academic, business, or government sectors is not sufficient. The present research has emphasized the key importance of boundary-spanning networking across all sectors by $1^{\text {st }}$ and $2^{\text {nd }}$ level influencers to achieve important community objectives, to build and sustain a regional innovation ecosystem, and to accelerate development through important mechanisms and processes.

We highlight several instances where influencers initiated mechanism and defined processes to facilitate collaboration across Austin's academic, business, government, and support sectors that facilitated the public-private collaboration needed to win the MCC in 1983; to fund endowed professorships 
and research center development at UT Austin; to launch the Austin Technology Incubator at UT Austin; to link state economic development funds and programs to university research; to transform UT Austin's Office of Technology Licensing to a more market oriented Office of Technology Commercialization; to build an entrepreneurial education support structure across the UT Austin campus; and to link economic development efforts of the city of Austin with those of the Greater Austin Chamber of Commerce and University of Texas.

Two cultural assets define Austin's DNA and have helped set the community apart from other regions that also have excellent research universities, public and private sector champions, and a high quality of life: One is the open and accepting "live and let live" or "Keep Austin Weird" culture that we suggest was born out of Austin's historic music and cultural venues and is sustained by Austin's current creative industries. It is important to emphasize that UT-Austin with its 50,000 students plus the region's other universities andcolleges are central to attracting a seemingly never ending flow of young talent which continually energizes Austin's creative and entrepreneurial culture. The second defining asset or characteristic is the cooperative "can do" attitude that technology, social, and civic entrepreneurs exhibit when coming together at important moments to implement regional action strategies.

An important limitation of this study is that it focuses on one case in which considerable assets and circumstances helped launch and sustain the Austin Technopolis including the winning of important national competitions for major R\&D operations, the discovery of oil on university land that has helped fund the education and research excellence at UT-Austin, and having a high quality of life exemplified by Austin's green rolling hills, lakes, an entrepreneurial culture sustained by young talent and a broad range of creative industries. In short, Austin enjoys important assets for community influencers to leverage to sustain the Austin Technopolis. While other regions in the US or in other nations may not enjoy such advantages, it is argued that all regions have positive assets -- whether human, geographic, cultural, or historic - that can be leveraged through publicprivate collaboration to overcome considerable challenges and to build creative and innovative ecosystems that are capable of producing wealth and jobs. We conclude that a key dimension of a sustainable technopolis strategy is the ability to grow and attract $1^{\text {st }}$ level influencers and to nurture $2^{\text {nd }}$ level influences that foster an environment of creative cooperation. Over the years, Austin has demonstrated that these influencers can come from the academic, business, government, or support sectors depending on a particular regional vision or challenge and depending who, at the time, occupies key positions of authority in each sector.

\section{REFERENCES}

Borgatti, S.P., Mehra, A., Brass, D., and Labianca, G.(2009) "Network Analysis in the Social Sciences," Science 323 (February 13) :892-5.

Butler, J.S.(2010) "Diffusion Theory and Business Eco-Systems: Lessons from Austin, Texas and the IC $^{2}$ Institute, The University of Texas at Austin," In The Development of University-Based Entrepreneurship Ecosystems: Global Practices, (Eds.) M. Fetters, P. Greene, M. Rice, and J.S. Butler (Northampton, MA:Edward Elgar). 99121.

Butler, J.(2010) "The University of Texas at Austin," in M. Rice, P. Green, and J.S. Butler (Eds.) Comparative Business Eco-Systems (Cheltenham, UK;Northampton, MA: Edward Elgar). 99-121.

Butler, J., and Gibson, D.V.(Eds.)(2011) Global Perspectives on Technology Transfer and Commercialization. (Cheltenham, UK;Northampton, MA: Edward Elgar).

Fetters, M., Geene, P., Rice, M., and Butler, J. (Eds.) (2010) The Development of University-Based Entrepreneurship Ecosystems: Global Practices. (Cheltenham, UK; Northampton, MA: Edward Elgar).

Florida, R.(2002) The Rise of the Creative Class: And How it's Transforming Work, Leisure, Community and Everyday Life. (New York: Basic Books).

Florida, R.(2005) "The World is Spiky," Atlantic Monthly (October 2005).

Gibson, D.V., Kozmetsky, G., and Smilor, R.W.(1992) The Technopolis Phenomenon: Smart Cities, Fast Systems, Global Networks. (Lanham, MD: Rowman \& Littlefield Publishers, Inc.)

Gibson, D.V., and Rogers, E.(1994) R\&D Collaboration on Trial (Boston, MA:Harvard Business School Press).

Nishizawa, A.(2011) "From Triple-Helix Model to Eco-system Building Model," International Journal of Technoentrepreneurship 2(3-4):304-23.

Ouchi, W. (1984) The M-Form Society: How American 
Teamwork can Recapture the Competitive Edge. (Menlo Park, CA: Addison-Wesley).

Phillips, F.(2006) Social Culture and High Tech Economic Development: The Technopolis Columns (Palgrave).

Phillips, F.(2008) "The Godfathers: Characteristics and Roles of Central Individuals in the Transformation of TechnoRegions," Journal of Centrum Cathedra 1(2): 12-27.

Powers, P. (2004) "Building the Austin Technology Cluster: The Role of Government and Community Collaboration in the Human Capital," unpublished paper.

Rogers, M., and Lawrence K.D. (1981) Communication Networks: A New Paradigm for Research (New York: Free Press).

Rogers, M., and Larsen, J.K. (1984) Silicon Valley Fever: Growth of High-Technology Culture (New York: Basic Books).

Rosenberg, D. (2002) Cloning Silicon Valley: The Next Generation High-Tech Hotspots (Pearson Education: New York).

Saxenian, A. (1994) Regional Advantage: Culture and Competition in Silicon Valley and Route 128. (Cambridge Mass.: Harvard University Press).

Smilor, R.W., Gibson, D.V., and Kozmetsky, G. (1988) "Creating the Technopolis: High-technology development in Austin, Texas," Journal of Business Venturing 4: 49-67.

Smilor, R.W., Kozmetsky, G., and Gibson, D.V. (1988) Creating the Technopolis: Linking Technology Commercialization and Economic Development. (Cambridge Mass.: Ballinger Publishing Company).

Smilor, R., O’Donnell, N., Stein, G., and Welborn III, R.S. (2007) "The Research University and the Development of High Technology Centers in the United States," Economic Development Quarterly 21(3, Aug.) : 20322.

Straubhaar, J., Spence, J., Tufekci, Z., and Lentz, R.G. (Eds.)(2012) Inequity in the Technopolis: Race, Class, Gender, and the Digital Divide in Austin, Texas.

Sunder, S.R. (1998) Austin, Texas: building a high-tech economy. White Paper N0.9-799-038. (Boston, Mass.: Harvard Business School Publishing).

Triple Helix Research Group (2013) "Triple Helix Concept" http://triplehelix.stanford.edu/3helix_concept (2013).

Viale, R., and Etzkowitz, H. (Eds.)(2010) The Capitalization of Knowledge: A Triple Helix of UniversityIndustry-Government (MA : Edward, Elgar Pub). 